\title{
The Effectiveness of Contemporary Islamic Scholars in Tackling Pornography Addiction: A Case of Muslim Students in Britain
}

ISSN: 2311-8636 (Print) ISSN: 2312-2021 (Online)

Licensed:



Source of Support: Nil

No Conflict of Interest: Declared

Email: hanaa251094@gmail.com

speak openly on pornography does not stop the prevalence of pornography among Muslim students. Therefore, the purpose is to explore the prevalence of pornography, its effect on Muslim students, and strategies to overcome pornography addiction. Through SPSS analysis, the numerical data shows that both Muslim male and female students view pornography regardless of its prohibitions. Some Muslim students are engaged in maladaptive behavior, affecting their spirituality, religion, and overall well-being (Ademola, 2017). The study, therefore, suggests alternative awareness programs to support Muslim students to overcome the struggles of pornographic addiction that is often too tempting to resist. Dealing with pornography per today's context perhaps will diminish the statistical rate of Muslim students watching pornography.

Keywords: Pornography, Muslim students, Shari'ah scholars, Fatwas

\section{INTRODUCTION}

Some Muslims have watched pornography intentionally and unintentionally (Quadri, 2013:101). Thus, throughout this study, the main discussion is worthy of attention to the awareness that needs to be addressed to support some Muslim students who cannot resist erotic and obscene images. This discussion shows that it is common human nature to feel attraction towards the opposite gender. Some Muslims often raise barriers as soon as the subjects of sexual activity and intimacy are broached, making it a difficult topic to discuss. Hence, many fail to produce advanced techniques to support Muslim students who are continually watching pornography.

\section{Statement of the Problem}

Various Muslim scholars have prohibited and condemned viewing pornographic images. For example, Shaykh Al- Uthaymīn believes that women should cover their private parts, 
but it is acceptable to reveal their face and hands in front of non-Muslim women by referring to the Qur'an, Surah An-Nur, Verse 30-31. He also adds in his fatwa that, if there is temptation involved, the women should cover more and ensure no part of her body is visible, whether in front of Muslim or non-Muslim women. In his fatwa essentialized from classical scholarship, all responsibility is passed on to women to cover their adornment. Similarly, Shaykh Ibn Baz says: "it is not permissible for a female to expose her adornment to the opposite gender unless it is her husband. If the woman decides to display her adornment, she will be a temptation source for men, allowing satan to allure and tempt both men and women [Fatawas regarding Women: Questions Related to Hijab, Dress, and Adornment (2019)].

Mufti Ismail Desai's fatwa on pornography is a major sin because it is a technological form of fornication or adultery. Pornography images are lifeless pictures that play the human mind and soul due to the eyes being polluted with evil on the screen. Desai further argues that pornography is worse than drug addiction since rehabilitation is a form of cure for drug addicts. In contrast, pornography addicts store pornographic images in their sight even if it is during a prayer - so the mental health is controlled by pornography [Fatwa approved by Mufti Ebrahim Desai (2012)]. Mufti Desai (2012) refers to the Qur'an (29:69), stating that individuals who are addicted to viewing pornography should be monitored while using the laptop. Pornography addicts should use the computer in an open space with people around. They should make minimum use of the internet. Besides, remember their Lord, the angel of death, the grave, control their desires, and make efforts to gain the love of Allah [Source: http://www.askimam.org/public/question_detail/22005].

Some scholars also ban married couples from taking nude pictures of their partners, which might lead to evil consequences (Ebrahim, 2008). For instance, the husband's belongings may be stolen or lost, and nude pictures may be spread far away and fall into the hands of people who would misuse those pictures. Looking at nude photos does not extinguish sexual desires; instead, it is the opposite. Therefore, the husband should protect his honor and his wife.

Another contemporary scholar, Shaykh Hamdi Benaissa, sees pornography as a modern disease. He states if a person was to choose between two sins; fornication or watching pornography. It is better to select fornication over pornography [Shaykh Hamdi Benaissa later concludes: "Allah protect from both sin and Allah is merciful"]. By watching pornography videos, a person can spread pornographic videos; thus, more people consume pornography videos. Those pornography images are stored in the human mind whilst making prostration to God (sujud). Hence, replacing pornographic content with historical or Islamic documentaries is much better (Benaissa, 2016). After analyzing various contemporary scholars' thoughts on pornography, it is evident that their fatwas are based on the framework set by the earlier classical figh [Source: The Memphis Da'wah Team.]. Even though the previous classical scholars' time, most modern developments in pornography were not available. The question that arises is whether previous rulings are adequate for current problems.

\section{Efforts of Muslim Scholars in Creating Awareness}

Today pornography is part of the modern culture. The pornography of today's culture has modified and desensitized Muslim attitudes towards sexuality (Akande, 2015). It affects both religious and irreligious communities across the globe. Pamela Paul (2007) states that "pornography messes with how a person thinks of a woman, where a person allures his 
spouse or girlfriend to be like the women on pornography". Similar research shows that pornography can dysfunctional relationships and no longer fulfill a person's ability to be intimidated (Akande, 2015:154). They visualize unrealistic expectations and feel their marriage is flawed in their intimacy and does not reach the scripted ideals. It has severe issues on self-esteem in which people begin to compare themselves to something that is staged. Hence, many relationships have fallen apart, unable to distinguish between reality and played (Quadri, 2013:101). Females are degraded, and neither is their respect for women nor good examples set for the family. Therefore, the addiction to pornography roots in adultery and fornication. The results of pornography are even seen in AIDS (Paul, 2007) due to sexual permissiveness (Mubabaya and Omar, 2009). It can dysfunctional the behaviors of many families and youngsters, which is evident in violence against females, gang rape, and AIDS (Paul, 2007:103).

Hence, Muslim scholars often refer to the Qur'anic verse (17:32), "And do not approach unlawful sexual intercourse [i.e., avoid all situations that might lead to it]. Indeed, it is ever an immorality and is evil as a way" to advise Muslims to distance themselves from sinning (Sayfuddin and Muhametov, 2004-2011:64). It shows that contemporary Shari'ah scholars and teachers suggest inculcating programs on loving Allah and his Messengers to help in actualizing virtuous deeds (taqwa: consciousness). They often suggest pornography addicts patiently persist in seeking beneficial information so that their souls can fight against themselves to obey Allah's command. At the same time, keep away from distraction and falsehood (Al-Uthaymeen, 2011:40). It further suggests that pornography viewers should avoid sinful company, get rid of their laptops unless used in public spheres, avoid looking at anything impermissible or marry as soon as possible (Al-Jibaly, 2006:104-106).

All these are suggestions from the traditionalist/ fundamentalist standpoint and not awareness. It is disappointing how innocent web surfing can lead to time-wasting and then into Haram. Hence, cautions to refrain from the evil that leads to insecurities and regret should not be overlooked (The Way of Islam, 2016). Thus, the limited solutions produced by Shari'ah scholars are not entirely convincing, as for some, these are temporary solutions. Chowdhury et al. (2016:67) suggest targeted treatment programs for sexual addiction, sexual abuse, and pornography abuse are needed to support individuals who are addicted to viewing pornography which may work if within an Islamic framework to cater to Muslim while not conflicting their religious norms. Therefore, it is imperative to provide extensive, specifically designed pornography addiction education programs to educate Muslim students about the adverse effects of pornography to investigate the possible gaps in long-term awareness (Chowdhury et al., 2016).

Moreover, the possible drawback of pornography awareness is associated with a lack of openness in discussion among some Muslims. This failure links to Shari'ah scholars and educators in not acknowledging that even during the Prophet Muhammad (PBUH) era, there was a rich tradition of speaking openly about sexuality among both genders. It was encouraged for solving sexual problems and for pleasure (Akande, 2016). Many years ago, several Muslim scholars wrote comprehensively about Arabic erotica and sex to cover conceivable sexual preferences, positions, and features. During the same period, many religious scholars, Muslim erotic writers, and sexual therapist shared their personal experiences relating to sexual behavior to educate and entertain the divine blessings of sexuality (Akande, 2016:2). In the 19th Century, we find the disappearance of Islamic contribution to the study of sexuality, and very little of erotological literature has survived 
today. It becomes challenging for Shari'ah scholars to educate Muslim students about pornography after the disappearance of Islamic contributions to the study of sexuality (Gulamhusein, 2018).

\section{Questionnaire Analysis: Descriptive and InfERential Statistics}

We can see from figure 1 more than half of the participants who took part in the survey were male, with a frequency of $51.58 \%$, therefore meaning that only $48.42 \%$ of women took part in the survey. It is not surprising, although the questionnaire was distributed to reachable Muslims by a female researcher. Considering that it can be somewhat challenging to access the Muslim community's female section, it suggests a distinct gender bias.

Figure 1: Basic demographic information of respondents

\begin{tabular}{|c|c|c|c|c|c|}
\hline \multicolumn{6}{|c|}{ (Q1) Gender } \\
\hline & & Frequency & Percent & Mean Value & Standard Deviation \\
\hline \multirow{3}{*}{ Valid } & Male & 49 & 51.58 & \multirow{3}{*}{1.1857} & \multirow{3}{*}{0.39168} \\
\hline & Female & 46 & 48.42 & & \\
\hline & Total & 95 & 100.0 & & \\
\hline \multicolumn{6}{|c|}{ (Q2) Age } \\
\hline \multirow{4}{*}{ Valid } & $20-25$ & 47 & 49.47 & \multirow{4}{*}{1.2421} & \multirow{4}{*}{0.29134} \\
\hline & $25-30$ & 31 & 32.63 & & \\
\hline & Above 30 & 17 & 17.89 & & \\
\hline & Total & 95 & 100.0 & & \\
\hline \multicolumn{6}{|c|}{ (Q3) Marital status } \\
\hline \multirow{5}{*}{ Valid } & Single & 46 & 48.42 & \multirow{5}{*}{2.1243} & \multirow{5}{*}{0.65875} \\
\hline & \begin{tabular}{|l} 
Married \\
\end{tabular} & 39 & 41.05 & & \\
\hline & Divorced & 9 & 09.47 & & \\
\hline & \begin{tabular}{|l} 
Wid owed \\
\end{tabular} & 1 & 01.05 & & \\
\hline & Total & 95 & 100.0 & & \\
\hline
\end{tabular}

Source: Authors survey questionnaire, 2020

A majority male response, most respondents were in the 20 to 25 -year-old range, representing a total of $49.47 \%$ of the age demography, and as such, highlighting the youthful makeup of the community. $50.52 \%$ of the respondents would fall within what would be considered the prime working-age, that of being above 25 years of age. This study is looking to assess the awareness of Muslim youth regarding pornography, and it is encouraging to see such a large percentage of the respondents within this age bracket.

\section{Awareness of Muslim Youth regarding Pornography}

Figure 2 assesses the participant's awareness of the issue of pornography encountered through media and the internet. $85.26 \%$ of respondents stated that they were 'definitely aware' or 'just aware' regarding the prohibition of pornography. Knowing the prohibition of pornography, not all participants are reminded of the prohibitions of pornography through Islamic sermons. Even though the majority of respondents stated that they knew pornography is Haram. For some, this awareness has not been the outcome of Islamic lectures and sermons, but perhaps due to other factors such as principles and morals within a particular society or culture, family upbringing, or pious friends. Hence, figures show that $51.57 \%$ of participants did not encounter lectures on pornography as it was hardly and often on no occasions delivered. Respondents questioned whether they received the directions and 
guidance on safe web surfing and mixed responses were received, with the mean value recording an average of 1.257. However, looking to the high standard deviation figure, we can see an extensive range of answers with no answer taking particular precedence. This high level of variation highlights that, although many people believe they have an idea of pornography. These ideas are somewhat different and personal, highlighting that available fatwas do not clearly explain the issue or protection guidance.

Figure 2: Perception of awareness

\begin{tabular}{|c|c|c|c|c|c|}
\hline \multicolumn{6}{|c|}{ (Q4) Are you aware that watching pornography is prohibitive in Islamic fiqh? } \\
\hline & & Frequency & Percent & Mean Value & Standard Deviation \\
\hline \multirow{6}{*}{ Valid } & Defin itely aware & 58 & 61.05 & \multirow{6}{*}{1.2571} & \multirow{6}{*}{0.52985} \\
\hline & Aware & 23 & 24.21 & & \\
\hline & Not sure & 6 & 6.32 & & \\
\hline & Not aware & 2 & 2.11 & & \\
\hline & Not at all aware & 6 & 6.32 & & \\
\hline & Total & 95 & 100.0 & & \\
\hline \multicolumn{6}{|c|}{$\begin{array}{l}\text { (Q5) In your classes/mosque lectures and sermons you have been regularly reminded about prohibition } \\
\text { of watching pornography? }\end{array}$} \\
\hline \multirow{6}{*}{ Valid } & Always & 22 & 23.16 & \multirow{6}{*}{1.5286} & \multirow{6}{*}{0.98865} \\
\hline & Sometimes & 24 & 25.26 & & \\
\hline & \begin{tabular}{|l} 
Neutral \\
\end{tabular} & 13 & 13.68 & & \\
\hline & Rarely & 20 & 21.05 & & \\
\hline & \begin{tabular}{|l} 
Never \\
\end{tabular} & 16 & 16.84 & & \\
\hline & Total & 95 & 100.0 & & \\
\hline \multicolumn{6}{|c|}{$\begin{array}{l}\text { (Q6) Your teachers/imams have made some suggestions how to stay safe using the internet and video } \\
\text { channels? }\end{array}$} \\
\hline \multirow{6}{*}{ Valid } & \begin{tabular}{|l} 
Strongly agree \\
\end{tabular} & 22 & 23.16 & \multirow{6}{*}{2.1434} & \multirow{6}{*}{1.24245} \\
\hline & Agree & 24 & 25.26 & & \\
\hline & \begin{tabular}{|l|} 
Neutral \\
\end{tabular} & 13 & 13.68 & & \\
\hline & \begin{tabular}{|l} 
Disagree \\
\end{tabular} & 20 & 21.05 & & \\
\hline & Strongly disagree & 16 & 16.84 & & \\
\hline & Total & 95 & 100.0 & & \\
\hline
\end{tabular}

Source: Authors survey questionnaire, 2020.

On the other hand, when the respondents were queried as to the guiding principles on pornography through lectures, $48.42 \%$ of respondents stated that they did receive suggestions and guidance on how to use the internet safely but whether these lectures were pornography focused remains a question. This response is supported by the mean value of 2.1434 and the standard deviation value of 1.24245 , meaning that the average response was recorded as being due to social benefits.

\section{Conscious about watching pornography}

Focused on the cognitive consequences of watching pornography and moral awareness resulting from fitrah (natural morality). This section's question asked respondents how pornography impacts their behavior, attitude, temptations, and beliefs. Having received a high response rate of $44.21 \%$ as seen in figure 3 , in which participants express the feeling of watching pornography not applying to them, it is not surprising among Muslim students to remain silent on controversial issues such as pornography. Thus, a large number of not applicable responses may refer to the concealment of pornography. Several 
publications stated: "pornography addicts often live a double or secret life because they hide their addition of pornography viewing from their loved ones due to shame" (Battle, 1440:6-8). Although for a few Muslim students' pornography is a remedy for sexual satisfaction (frequency 8) and relief (frequency 6), it still does not contain the human nafs. It leads to regret and sorrow as $30.53 \%$ of Muslim students have specified.

Figure 3: Fitrah and pornography

\begin{tabular}{|c|c|c|c|c|c|}
\hline \multicolumn{6}{|c|}{ (Q7) If you ever watched pornography how does that make you feel? } \\
\hline & & Frequency & Percent & Mean Value & Standard Deviation \\
\hline \multirow{8}{*}{ Valid } & Satisfies my sexual needs & 8 & 8.42 & \multirow{8}{*}{4.2429} & \multirow{8}{*}{1.12205} \\
\hline & Makes me feel less lonely & 4 & 4.21 & & \\
\hline & $\begin{array}{l}\text { I forget about my daily } \\
\text { worries }\end{array}$ & 6 & 6.32 & & \\
\hline & Makes me regret & 29 & 30.53 & & \\
\hline & Makes me sacrifice things & 4 & 4.21 & & \\
\hline & Not applicable & 42 & 44.21 & & \\
\hline & Other & 2 & 2.11 & & \\
\hline & Total & 95 & 100.0 & & \\
\hline \multicolumn{6}{|c|}{ (Q8) Does watching the pornography influence your behaviour raising the concerns? } \\
\hline \multirow{6}{*}{ Valid } & $\begin{array}{l}\text { I have no concerns about } \\
\text { my sexual beh aviour }\end{array}$ & 50 & 52.63 & \multirow{6}{*}{1.3171} & \multirow{6}{*}{1.15971} \\
\hline & $\begin{array}{l}\text { Others are concerned } \\
\text { about my sexual } \\
\text { behaviour }\end{array}$ & 8 & 8.42 & & \\
\hline & $\begin{array}{l}\text { I am struggling with my } \\
\text { sexual urges and/or my } \\
\text { gaze }\end{array}$ & 18 & 18.95 & & \\
\hline & I am sexually addicted & 10 & 10.53 & & \\
\hline & Other & 9 & 9.47 & & \\
\hline & Total & 95 & 100.0 & & \\
\hline \multicolumn{6}{|c|}{$\begin{array}{l}\text { (Q9) Internet can be a useful tool when used for the right reasons, but what about other reas ons, } \\
\text { such as pornography. Which of the following is affecting porn viewers the most? }\end{array}$} \\
\hline \multirow{9}{*}{ Valid } & $\begin{array}{l}\text { Memorisation and } \\
\text { studying }\end{array}$ & 16 & 16.84 & \multirow{9}{*}{3.5429} & \multirow{9}{*}{1.24744} \\
\hline & Focus and concentration & 9 & 9.47 & & \\
\hline & $\begin{array}{l}\text { Marital and pre-marital } \\
\text { relationships }\end{array}$ & 14 & 14.74 & & \\
\hline & Sexuality & 11 & 11.58 & & \\
\hline & Morals and beliefs & 21 & 22.11 & & \\
\hline & Simplicity and innocence & 11 & 11.58 & & \\
\hline & Lifestyle and performance & 7 & 7.37 & & \\
\hline & Other (please specify) & 6 & 6.32 & & \\
\hline & Total & 95 & 100.0 & & \\
\hline
\end{tabular}

Source: Authors survey questionnaire, 2020.

Moving back to non-applicable responses in question 7 , it links to question 8 , where $52.63 \%$ of Muslim students have no concerns about their sexual behavior. There are high possibilities that both answers were responded to by the same individuals who do not wish to declare their problems of sex drive due to ongoing taboo. Supported by the mean value of 4.2429, situating the average response within the category "makes me regret" and a low standard deviation value of 1.12205. Meaning that the main problem of pornography is huge regret among the Muslim students as a result of wasting time on the things which are not beneficial and brings curse and sins on the watchers. 
In contrast, honest disclosure of $18.95 \%$ in which participants have stated that they are struggling with their sexual urges and lowering their gaze and 10.53\% are sexually addicted, which a considerable challenge for the ummah in the 21st Century. When looking at the figures, $26.32 \%$ of participants stated that such consequences would affect marital and pre-marital relationships and sexuality among Muslim students who view pornography. Previous studies have shown that, when a man views pornography on the internet or in magazines, he will consider his wife less attractive (Morris \& Perry, 2017). Both men's and women's sexual satisfaction decreases after watching pornography hence lowering their judgments about average people's attractiveness (Bergner and Bridges, 2002). The overall statistics prove that participants are either unsure or not familiar with pornography awareness. There is a general lack of knowledge surrounding fighi issues on pornography and how it should be handled.

Furthermore, participants' highest frequency stated that the morals and beliefs of pornography viewers were more likely to be affected because pornography is Islam prohibited. Likewise, the survey collected by Harris in the United States in 2009, shows that only $15 \%$ believe pornography is morally acceptable, whereas $76 \%$ consider it immoral. Viewing pornography takes away humankind's simplicity, causing negative lifestyle changes and equally affects focus and memorization. All possibilities are strongly linked together and lead to disaster, which is evident in the similar frequency of probable effects.

\section{Perception of Guidance on Pornography}

Figure 4 assesses the participant's perceptions of available efforts in protecting the Muslim youth of negative implications of watching pornography through mosques and social media. When asked about $43.16 \%$ of participants either 'agreed strongly', or 'agreed' that there is adequate nudity guidance. A slightly higher percentage of $44.21 \%$ 'strongly disagreed' and 'disagreed' that existing Islamic education in the Mosques and social media provides the right direction for dealing with pornography. We currently live in a highly advanced digital era where technology has invaded every aspect of human lives through increased access to the internet. Most fatwas still do not seem to tackle the prevalence of pornography among Muslim students. The mean value was 2.4342 , which situates the average response between agreeing and disagree, which is in line with the percentages stated.

Muslim students were whether more guidance should have been provided to protect boys and girls. A large proportion of $88.42 \%$ 'strongly agreed' and 'agreed' that there is a significance in spreading more awareness among Muslim students due to the increased fitnah in today's world. A minority of $8.42 \%$ of respondents stated that they 'strongly disagreed' and 'disagreed' that there is a need to provide more guidance, which remains a matter of some Muslims disregarding realities of pornography addiction among Muslim students that need resolving. Questions' mean values were 2.4342 and 1.4714 , meaning high response was between strongly agree and agree, with minimal deviation. Therefore, in question 12; 78.58\% of participants were 'not sure', 'not aware', and 'not aware at all' if there was any support provided by Imams and Muslim therapists for Muslim pornography viewers.

A small figure of $28.42 \%$ of participants was 'definitely aware' and 'aware' of the support supplied to Muslim pornography addicts. The small number of percentages may refer to support provided via YouTube channels or online blogs. Certainly not productive to treat 
Muslim pornography viewers because it is observed that many people including children are victimized by the social damage of pornography (Mubabaya and Omar, 2009). Pornography damages are apparent in growing and ongoing marital and pre-marital affairs prevailing globally. The last question's mean values were 2.6857, meaning that the high response was between 'aware' and 'not sure'.

Figure 4: Efforts in combating pornography

\begin{tabular}{|c|c|c|c|c|c|}
\hline \multicolumn{6}{|c|}{$\begin{array}{c}\text { (Q10) Does existing Is la mic education in the Mosques/class/social media provides adequate } \\
\text { guidance how to deal with pornography and nudity around? }\end{array}$} \\
\hline & & Frequency & Percent & Mean Value & Stand ard Deviation \\
\hline \multirow{6}{*}{ Valid } & Strongly agree & 20 & 21.05 & \multirow{6}{*}{2.4342} & \multirow{6}{*}{0.73030} \\
\hline & Agree & 21 & 22.11 & & \\
\hline & \begin{tabular}{|l|} 
Neutral \\
\end{tabular} & 12 & 12.63 & & \\
\hline & Disagree & 36 & 37.89 & & \\
\hline & \begin{tabular}{|l|} 
Strongly disagree \\
\end{tabular} & 6 & 6.32 & & \\
\hline & Total & 95 & 100.0 & & \\
\hline \multicolumn{6}{|c|}{$\begin{array}{c}\text { (Q11) Do you agree that much more awareness and guidance could be provided to protect boys } \\
\text { and girls in this challenging time? }\end{array}$} \\
\hline \multirow{6}{*}{ Valid } & Strongly agree & 53 & 55.79 & \multirow{6}{*}{1.4714} & \multirow{6}{*}{0.52074} \\
\hline & \begin{tabular}{|l|} 
Agree \\
\end{tabular} & 31 & 32.63 & & \\
\hline & Neutral & 3 & 3.16 & & \\
\hline & Disagree & 3 & 3.16 & & \\
\hline & Strongly disagree & 5 & 5.26 & & \\
\hline & Total & 95 & 100.0 & & \\
\hline \multicolumn{6}{|c|}{$\begin{array}{l}\text { (Q12) Are you aware about any support provide by imams, teachers Muslim therapists for people } \\
\text { who are addicted in watching porn? }\end{array}$} \\
\hline \multirow{6}{*}{ Valid } & Definitely aware & 17 & 17.89 & \multirow{6}{*}{2.6857} & \multirow{6}{*}{1.62654} \\
\hline & Aware & 10 & 10.53 & & \\
\hline & \begin{tabular}{|l|} 
Not sure \\
\end{tabular} & 18 & 18.95 & & \\
\hline & \begin{tabular}{|l|} 
Not aware \\
\end{tabular} & 22 & 23.16 & & \\
\hline & Not at all aware & 28 & 29.47 & & \\
\hline & Total & 95 & 100.0 & & \\
\hline
\end{tabular}

Source: Authors survey questionnaire, 2020.

Therefore, the results showed that most respondents are aware of pornography, but there is a lack of support provided by Shari'ah scholars and Muslim educators. Participants currently suffer from a lack of knowledge and awareness. Perhaps due to Mass Media's competitiveness in using erotic scenes that have not been controlled remarkably by law enforcement and the urban community (Sinaulan, 2017).

It may bring a rising problem for Muslim students due to the emerging media manifestation for freedom and decreasing the social control by the government and the community itself.

\section{Inferential Statistical Analysis: Cross Referencing amongst the Independent Variables}

To further analyze the same data set, cross-referencing the control categories, of age, gender, and marital status with the variable questions. The Kruskal-Wallis test is employed to analyze the data set, looking for statistically significant differences that may have arisen. 
Figure 5: Difference in Perception among group categories

\begin{tabular}{|c|c|c|c|c|c|c|c|c|c|}
\hline Question & Age & $\begin{array}{c}\text { Mean } \\
\text { rank }\end{array}$ & $\begin{array}{c}\text { Asymp } \\
\text {.sig }\end{array}$ & Gender & $\begin{array}{c}\text { Mean } \\
\text { rank }\end{array}$ & $\begin{array}{c}\text { Asymp. } \\
\text { sig }\end{array}$ & $\begin{array}{c}\text { Marital } \\
\text { Status }\end{array}$ & $\begin{array}{l}\text { Mean } \\
\text { rank }\end{array}$ & $\begin{array}{l}\text { Asymp. } \\
\text { sig }\end{array}$ \\
\hline $\begin{array}{l}\text { (Q4) Are you aware that } \\
\text { watching pornography is } \\
\text { proh bitive in Islam ic } \\
\text { fiqh? }\end{array}$ & $\begin{array}{l}20-25 \\
26-30 \\
\text { Above } 30\end{array}$ & $\begin{array}{l}36.18 \\
31.57 \\
27.79\end{array}$ & .260 & $\begin{array}{l}\text { Male } \\
\text { Female }\end{array}$ & $\begin{array}{l}35.79 \\
34.23\end{array}$ & .764 & $\begin{array}{l}\text { Single } \\
\text { Married } \\
\text { Divorced } \\
\text { Widowed }\end{array}$ & $\begin{array}{l}36.07 \\
34.75 \\
17.34 \\
11.21\end{array}$ & .064 \\
\hline $\begin{array}{l}\text { (Q5) In your } \\
\text { classes/mosque lectures } \\
\text { and sermons you have } \\
\text { been regularly reminded } \\
\text { about prohibztion of } \\
\text { watching pornography? }\end{array}$ & $\begin{array}{l}20-25 \\
26-30 \\
\text { Above } 30\end{array}$ & $\begin{array}{l}35.71 \\
34.93 \\
31.43\end{array}$ & .886 & $\begin{array}{l}\text { Male } \\
\text { Female }\end{array}$ & $\begin{array}{l}33.90 \\
42.50\end{array}$ & .073 & $\begin{array}{l}\text { Single } \\
\text { Married } \\
\text { Divorced } \\
\text { Widowed }\end{array}$ & $\begin{array}{l}35.48 \\
50.50 \\
22.34 \\
25.95\end{array}$ & $.043^{*}$ \\
\hline $\begin{array}{l}\text { (Q6) Your teachers/ } \\
\text { imams have made some } \\
\text { suggestions how to stay } \\
\text { safe using the internet } \\
\text { and video channels? }\end{array}$ & $\begin{array}{c}20-25 \\
26-30 \\
\text { Above } 30\end{array}$ & $\begin{array}{l}34.27 \\
29.29 \\
44.50\end{array}$ & .801 & $\begin{array}{l}\text { Male } \\
\text { Female }\end{array}$ & $\begin{array}{l}35.41 \\
35.88\end{array}$ & .937 & $\begin{array}{l}\text { Single } \\
\text { Married } \\
\text { Divorced } \\
\text { Widowed }\end{array}$ & $\begin{array}{l}36.07 \\
46.40 \\
27.34 \\
11.21 \\
\end{array}$ & .937 \\
\hline $\begin{array}{l}\text { (Q7) If you ever watched } \\
\text { porno how does that } \\
\text { make you fe el? }\end{array}$ & $\begin{array}{l}20-25 \\
26-30 \\
\text { Above } 30\end{array}$ & $\begin{array}{l}36.54 \\
35.33 \\
33.00\end{array}$ & $.018^{*}$ & $\begin{array}{l}\text { Male } \\
\text { Female }\end{array}$ & $\begin{array}{l}36.50 \\
31.12\end{array}$ & .230 & $\begin{array}{l}\text { Single } \\
\text { Married } \\
\text { Divorced } \\
\text { Widowed }\end{array}$ & $\begin{array}{l}36.39 \\
40.29 \\
26.81 \\
18.00\end{array}$ & .230 \\
\hline $\begin{array}{l}\text { (Q8) Does watching the } \\
\text { pornography influe nce } \\
\text { your behaviour raising } \\
\text { the concerns? }\end{array}$ & $\begin{array}{l}20-25 \\
26-30 \\
\text { Above } 30\end{array}$ & $\begin{array}{l}36.54 \\
35.33 \\
33.00\end{array}$ & $.017^{*}$ & $\begin{array}{l}\text { Male } \\
\text { Female }\end{array}$ & $\begin{array}{l}36.50 \\
31.12\end{array}$ & .230 & $\begin{array}{l}\text { Single } \\
\text { Married } \\
\text { Divorced } \\
\text { Widowed }\end{array}$ & $\begin{array}{l}38.64 \\
30.96 \\
26.83 \\
20.01\end{array}$ & .114 \\
\hline
\end{tabular}

Source: Authors survey questionnaire, 2020.

It can be seen from figure 5 that there is no statistically significant difference exist within the control categories when cross-referenced with questions 4, 5, 6, 7, and 8 . However, we see that age affects the consciousness among the watchers of pornography, which triggers moral wakening, with a p-value of 0.18 . Observation of importance is noted when analyzing the marital status group's difference in question 5. According to the KruskalWallis test, there exists more knowledge amongst the married Muslim students on the perception of pornography through religious education. The $\mathrm{p}$-value recorded in this record is very low at 0.43 whilst the median scores for married 50.50 and 38.48 amongst singles. Interestingly no significant value was observed when cross-references with gender category.

In figure 6, the questions centered on the perceptions of pornography effects and available support provided by the Muslims. There were significant statistical differences found across age and marital status when discussing questions such as the 10 and 12 among age and 10 and 11 among marital status. The gender was only significant in question. We can see that with a p-value of .046 there is a statistically substantial variety of perceptions relating to this question per age. The median value of 44.93 for the age group 26-30 shows that they had a distinctly different understanding to the rest of the sample. It also signifies the participants' maturity in understanding the importance of making awareness.

The impact of gender in question 9, on perception and understanding the effectiveness of internet and media use among Muslim students with a p-value of .024 registered when cross-referenced among female and male. It is interesting to notice variations among the gender in the use of the internet by observing a median value of 56.23 recorded amongst the female, which suggests that they might perceive the internet more seriously as a tool that significantly impacts them. 
Figure 6: Difference in perceptions among group categories

\begin{tabular}{|c|c|c|c|c|c|c|c|c|c|}
\hline Question & Age & $\begin{array}{c}\text { Mean } \\
\text { rank }\end{array}$ & $\begin{array}{c}\text { Asymp.s } \\
\text { ig }\end{array}$ & Gender & $\begin{array}{c}\text { Mean } \\
\text { rank }\end{array}$ & $\begin{array}{l}\text { Asymp } \\
\text {.sig }\end{array}$ & $\begin{array}{c}\text { Martial } \\
\text { Status }\end{array}$ & $\begin{array}{l}\text { Mean } \\
\text { rank }\end{array}$ & $\begin{array}{c}\text { Asymp.s } \\
\text { ig }\end{array}$ \\
\hline $\begin{array}{l}\text { (Q9) Internet can be a } \\
\text { useful tool when used } \\
\text { for the right reasons, } \\
\text { but what about other } \\
\text { reasons, such as } \\
\text { pornography. Which of } \\
\text { the following is affect ing } \\
\text { porn viewers the most? }\end{array}$ & $\begin{array}{c}20-25 \\
26-30 \\
\text { Above } 30\end{array}$ & $\begin{array}{l}36.18 \\
31.57 \\
27.79\end{array}$ & .260 & $\begin{array}{c}\text { Male } \\
\text { Female }\end{array}$ & $\begin{array}{l}35.79 \\
56.23\end{array}$ & $.024^{*}$ & $\begin{array}{c}\text { Single } \\
\text { Married } \\
\text { Divorced } \\
\text { Widowed }\end{array}$ & $\begin{array}{l}36.07 \\
34.75 \\
17.34 \\
11.21\end{array}$ & .764 \\
\hline $\begin{array}{l}\text { (Q10) Does existing } \\
\text { Islamic education in the } \\
\text { Mosques/class/social } \\
\text { media provides adequate } \\
\text { guidance how to deal with } \\
\text { pornography and nudty } \\
\text { around? }\end{array}$ & $\begin{array}{c}20-25 \\
26-30 \\
\text { Above } 30\end{array}$ & $\begin{array}{l}39.71 \\
44.93 \\
31.43\end{array}$ & $.046^{*}$ & $\begin{array}{c}\text { Male } \\
\text { Female }\end{array}$ & $\begin{array}{l}33.90 \\
42.50\end{array}$ & .083 & $\begin{array}{c}\text { Single } \\
\text { Married } \\
\text { Divorced } \\
\text { Widowed }\end{array}$ & $\begin{array}{l}56.07 \\
34.75 \\
17.34 \\
11.21\end{array}$ & $.043^{*}$ \\
\hline $\begin{array}{l}\text { (Q11) Do you agree that } \\
\text { much more awareness } \\
\text { and guidance could be } \\
\text { provided to protect boys } \\
\text { and gir's in this } \\
\text { challenging time? }\end{array}$ & $\begin{array}{c}20-25 \\
26-30 \\
\text { Above } 30\end{array}$ & $\begin{array}{l}37.17 \\
34.27 \\
29.29\end{array}$ & .801 & $\begin{array}{c}\text { Male } \\
\text { Female }\end{array}$ & $\begin{array}{l}35.41 \\
35.88\end{array}$ & .937 & $\begin{array}{c}\text { Single } \\
\text { Married } \\
\text { Divorced } \\
\text { Widowed }\end{array}$ & $\begin{array}{l}35.32 \\
55.41 \\
21.34 \\
35.88\end{array}$ & $.037^{*}$ \\
\hline $\begin{array}{l}\text { (Q12) Are you aware } \\
\text { about any support } \\
\text { provide by imams, } \\
\text { teachers Muslim } \\
\text { therapists for people } \\
\text { who are addicted in } \\
\text { watching porn? }\end{array}$ & $\begin{array}{c}20-25 \\
26-30 \\
\text { Above } 30\end{array}$ & $\begin{array}{l}46.54 \\
35.33 \\
33.00\end{array}$ & $.027^{*}$ & $\begin{array}{c}\text { Male } \\
\text { Female }\end{array}$ & $\begin{array}{l}36.50 \\
31.12\end{array}$ & .230 & $\begin{array}{c}\text { Single } \\
\text { Married } \\
\text { Divorced } \\
\text { Widowed }\end{array}$ & $\begin{array}{l}42.21 \\
36.50 \\
31.12 \\
12.10\end{array}$ & .230 \\
\hline
\end{tabular}

Source: Authors survey questionnaire, 2020.

There were two responses worthy of closer attention within figure 6, namely questions 10 and 11 when cross-referenced with the marital status group. In response to question 10, marital status had a significant impact on whether or not available Islamic education in the class or mosque provides adequate guidance. Single category more diversified opinions on the adequacy of existing tools in guiding the youth, registering a median value of 56.07 and a p-value from the data set of .043. In response to question 11 married respondents were statistically different from the rest of the data set, recording a median value of 55.41 followed by a single 35.32 respectively, with a p-value for this question of .037.

It is clear from descriptive statistics that the issue of pornography prevailing among Muslim students. The classical approaches articulated today are not useful in combating the negativities of pornography. There is quite a large number who have regret feeling watching pornography which has further implications on daily routine, studying, and memorizing. So, combating the negatives, more comprehensive approaches such as designing oriented courses for a different age group to educate Muslims about sexuality and the consequences of watching prohibitive pornographic materials. From the Kruskal-Wallis analysis, we can see that most Muslim student respondents have understood the issue of pornography and the fundamental differences between group categories of age and marital status. It also noticed the inadequate Islamic education and guidance on pornography catered to Muslim students. Throughout the analysis, the impact of age and marital status is significant, with more statistical variances recorded across these control categories than any other. 


\section{DISCUSSION AND FINDINGS}

Survey analysis shows behavioral concerns around sexuality for both genders. It is uncertain whether watching pornography helps Muslim males more than it allows females to understand sexuality due to the high ratio of female (8) compared to male (3) participants who believed that viewing pornography affects their sexuality. Three male participants had no sexual concerns similar to 4 female participants, whilst the other four female participants had sexual concerns but believed pornography satisfied their sexual needs knowing it is prohibited. Muslim scholars should, therefore engage in more profound thoughts on tackling pornography addiction. Thus, a significant number of Muslims have concerns around focus, concentration, memorization, studies, sexual behavior, lowering the gaze, and marital and pre-marital relationships due to pornography. Acknowledging that Muslim males and females are victims of pornography, it cannot distinguish that both genders are exposed to online nudity that equally damages their quality of life. Indeed, pornography changes human perception and damages human lifestyle. Social changes around nudity and immorality can occur due to other cultures' influence or population growth (Soekamto, 1997).

The world is mounting toward explicit sexual practices. Its outcome is seen in complex discussions around pornography whereby Muslim students fear their parents and fear being judged by others, impacting their reputation (Yahyaoui et al., 2013). The increased fear of viewing pornography among many Muslim students is due to the absence of suitable pornography therapy. Thus, awareness is the most common theme throughout the quantitative data results. The participants' male $(35.41 \%)$ and female $(35.88 \%)$ places almost equal significance on more enhanced awareness to protect Muslim students. Although there is a lack of awareness concerning solutions for pornography, there is a notable trend seen when conducting the inferential statistical analysis: the link between age, gender, and marital status, and the level of understanding regarding pornography. A significant number of single and then married Muslim students agreed that combatting today's challenges requires Shari'ah scholars to implement pornography awareness or specialized programs suitable within the Islamic framework.

It appears that there is a need for more engagement of Shari'ah scholars in providing numerous tools to withstand pornography. Recent research by Gulamhusein (2018:18) suggests that more educational outreach materials, workshops, and presentations on seeking pornography, pitfalls of pornography, and measures need to be taken and placed into Islamic education and taught to Muslim students. With the overwhelming lack of awareness concerning pornography, the public appears alienated from Muslim educators' additional support. In contrast, non-Muslims actively introduce accessible, innovative therapies.

There is a lack of engagement and inadequate awareness programs on pornography delivered to Muslim students, as many educators do not know how to deal with the concerning issue. However, during the classical Islamic era conversations around sex and sexuality were easily tackled. The modern scholarship mainly repeats the solution from when pornography did not even exist. It shows some Muslims found not to speed with current educational practices and thinking (Cherti and Bradley, 2011:12). Some may give the impression that pornography is not a problem among Muslims, although analysis discovered that Muslim students could not stop viewing pornography for several reasons. Hence there is a need to establish some counseling like projects for Muslim pornography viewers. 


\section{CONCLUSION}

The prevalence of internet pornography did not exist in the wake of Islam; hence Muslim scholars referred to the classical text with discussions focused on fahisha, munkar, awrah, and zinah. Thus, contemporary scholars rely on fatwas, but these fatwas are repetitions of classical text. They often do not fit into the modern context. Muslim scholars produced fatwas based on temporary solutions such as getting married, lowering gaze, fasting, and avoiding web surfing to evade pornography viewing. However, these solutions may not fit the needs of all Muslim students. Hence these temporary solutions by Shari'ah scholars may not be effective. Many Shari'ah scholars make efforts to create awareness by providing temporary solutions to tackle the negative implications of pornography. However, often disapproving and narrow approaches are in place to support Muslim students who are addicted to pornography.

\section{REFERENCES}

Ademola, Y. A. (2017). The Effect of Religiosity on Prevalence of Behavioural Addiction Among is Muslim Adolescents in High Schools in Lagos, Nigeria, Thesis Submitted to International Open University, Gambia. Available at: https://documentcloud.adobe.com/link/track?uri=urn $\% 3$ Aaaid $\% 3$ Ascds $\% 3 A U S \% 3$ A892572d6-f108-44fb-9102-c90ff1b7010a

Akande, H. (2015). A Taste of Honey: Sexuality and Erotology in Islam. London: Rabaah Publisher.

Akande, H. (2016). Islamic Erotic Literature: An Introduction to Arab-Muslim Erotology, Conference Presentation at Words of Desire: The Language of Arabic Erotica and its Translations at Institut du Monde Arabe (Arab World Institute), Paris, France on 6 May, pp. 1-8.

Al-Jibaly, M. (2006). Closer than a Garment: Marital Intimacy According to the Pure Sunnah. (The Muslim Family 2). Al-Kitaab and as-Sunnah Publishing. Available at: https://docs.google.com/file/d/0BxNIxc4ya9sDUHZkUXhmSG4wT3M/view

Al-Uthaymeen, S. M. S. (2011) ( $2^{\text {nd }}$ ed.) Youth's Problems: Issues that Affect Young People Discussed in the Light of the Qur'an and the Sunnah. Riyadh: International Islamic Publishing House.

Benaissa, Hamdi. (2016). Muslims Watching Pornography. YouTube. [ONLINE]. Available at: $\quad$ https://www.youtube.com/watch?time_continue=650\&v=_TA2-MDINOY [Accessed 22 December 2020].

Bergner, R. M., \& Bridges, A. J. (2002). The Significance of Heavy Pornography Involvement for Romantic Partners: Research and Clinical Implications. Journal of Sex \& Marital Therapy, 28(3), 193-206, https:/ / doi.org/10.1080/009262302760328235

Cherti, M., and Bradley, L. (2011:12). Inside madrassas: Understanding and engaging with British-Muslim faith supplementary schools. Institute for Public Policy Research (IPPR), London WC2N 6D, November 2011.

Chowdhury, R. H. K., Chowdhury, K. R. M., Kabir, R., Perera, P. K. N., and Kader, M. (2018). Does the Addiction in Online Pornography: Affect the Behavioral Pattern of Undergrad Private University Students in Bangladesh? in International Journal of Health Sciences, Qassim University, June, Vol. 12, No. 3, pp. 67-74. ISSN: 1658-3639. 
Ebrahim, A. F. (2008). A Compilation of Fatawa (edicts) of Different Scholars and Institutions on Issues relating to Love, Sex, and Rape. (Also Including Some Additional Medical or Other Matter). September, pp. 1-171.

Govt. UK. (1959). Obscene Publications Act 1959, in CHAPTER 667 and 8 Eliz 2. Available at: https://www.legislation.gov.uk/ukpga/Eliz2/7-8/66

Gulamhusein, S. (2018). Pornography Addiction: An Epidemic. Inspirited Minds Research Report. Available at: https://inspiritedminds.org.uk/wpcontent/uploads/2018/05/IM-Research-Report-Pornography.pdf

Islam Web - English Fatwa. (2014). Is Watching Pornography Film a Grave Major Sin? [ONLINE]. Available at: https://www.islamweb.net/en/fatwa/27224/is-watchingpornography-films-a-grave-major-sin [Accessed 19 December 2020].

Islam web - English Fatwa. (2014). Practical Solutions for the Problem of Pornography

[ONLINE].

Available

at: https:/ / www.islamweb.net/en/fatwa/260788/practical-solutions-for-the-problemof-pornography-addiction [Accessed 14 December 2020].

Islam web - English Fatwa. (2014). She Watches pornography to satisfy her husband. [ONLINE]. Available at: https://www.islamweb.net/en/fatwa/237490/she-watchespornography-to-satisfy-her-husband [Accessed 14 December 2020].

Islam web - English Fatwa. (2016). How to Treat Addiction to Pornography. [ONLINE]. Available at: https://www.islamweb.net/en/fatwa/311356/how-to-treat-addictionto-pornography [Accessed 14 December 2020].

Islam.ru. (2019). Story of Barsisa, The worshipper. [ONLINE] Available at: http://islam.ru/en/content/story/story-barsisa-worshipper [Accessed 13 December 2020].

Morris, E. W., \& Perry, B. L. (2017). Girls Behaving Badly? Race, Gender, and Subjective Evaluation in the Discipline of African American Girls. Sociology of Education, 90(2), 127-148. https://doi.org/10.1177/0038040717694876

Mubabaya, P. U. A., and Omar, M. (2009). Islam the Solution to Worlds Perplexing Social Problems. International Islamic Publishing. ISBN: 9960-672-09-3.

Mufti Ebrahim Desai. (2012). Pornography and Masturbation Addiction | Public Ask Imam. [ONLINE] Available at: http://www.askimam.org/public/question_detail/22005 [Accessed 20 December 2020].

Mufti Ismail Desai. (2012). Pornography and Masturbation Addiction | Fatwa number: 22005. Public Ask Imam. [ONLINE] Available at: http://www.askimam.org/public/question_detail/22005 [Accessed 22 December 2020].

Paul, P. (2007). Pornography: How Pornography is Transforming Our Lives, Our Relationships, and Our Families. New York: Macmillan. ISBN: 1429900792, 9781429900799.

Quadri, H. and Quadri, S. (2013). The War within Our Hearts. Markfield: Kube Publishing LTD.

Sayfuddin, M. and Muhametov, R. A. (2004-2011). Love \& Sex in Islam. Publishing House Ansar. ISBN: 978-5-98443-040-1. 
Shaykh Al- Uthaymīn and Shaykh Ibn Baz. (2019). Fatawas Regarding Women | Questions Related to Hijab, Dress, and Adornment. [ONLINE] Available at: https://www.kalamullah.com/hijab.html\#land. [Accessed 19 December 2020].

Sinaulan, L. R. (2017). The Implementation Effort Islamic Law Norms in Activities for Overcoming Pornography and Pornographyoaction on Mass Media, in International Journal of Nusantara Islam, Vol. 05, No. 01, pp. 1-12. DOI: https://dx.doi.org/10.15575/ijni.v5i1544

Soekamto, T. (1997). Teori Belajar dan Model Pembelajaran Pusat antar Universitas. Jakarta

The Memphis Da'wah Team. "Fatwa Concerning Looking" Compiled and Translated by Those who Seek the Mercy of Allah Their Lord. Issue, 1-13, pp. 2-23.

The Qur'an: English meanings and Notes by Saheeh International. Translated by Bantley, A.J., Umm Mohammad, A.A. and Kennedy, M.M. (2012). Jeddah: Al-Muntada Al-Islami.

The Way of Islam. (2016). Fornication, Adultery, Masturbation, Pornography, Oral, and Anal Sex: FAQ: In the Hadith and the Quranic Verses. CreateSpace Independent Publishing Platform. Partly Available at: https://centralmosque.com/index.php/Relationships/fornication-adultery-masturbation-apornography.html.

Yahyaoui, A., El Methni, M., Gaultier, S., and Lakhdar-Yahyaoui, D. B. H. (2013). Acculturative processes and adolescent sexuality: A comparative study of 115 immigrant adolescents from cultures influenced by Islam and 115 French adolescents from cultures influenced by Christianity, in International Journal of Intercultural Relations, Vol. 27, p. 28-47.

\section{How to cite this article:}

Amir, H. S. (2020). The Effectiveness of Contemporary Islamic Scholars in Tackling Pornography Addiction: A Case of Muslim Students in Britain. Asian Journal of Humanity, Art and Literature, 7(2), 123-136. https://doi.org/10.18034/ajhal.v7i2.531 